\title{
PENDIDIKAN MULTIKULTURAL DALAM PENGEMBANGAN KURIKULUM PERGURUAN TINGGI (Sebuah Kajian Kurikulum)
}

\author{
Kapraja Sangadji \\ Dosen Fakultas Ilmu Tarbiyah dan Keguruan IAIN Ambon \\ E-mail: federalhatuhaha@gmail.com
}

\begin{abstract}
Abstrak: Pengembangan dan Implementasi pendidikan multikultur pada pendidikan tinggi, dapat dikemas ke dalam muatan kurikulum seperti pendidikan kewargaanegaraan, prinsip-prinsip pendidikan multikultural, landasan pendidikan mutikultural dan pendidikan keberagamaan dilakukan serta dapat dilakukan melalui hidden kurikulum atau sentuhan dalam konteks pembinaan akhlak mulia, memiliki intensitas untuk membina dan mengembangkan kerukunan hidup antar umat beragama. Olehnya itu, pendidikan multikultural ini bisa dimasukkan sebagai kurikulum perguruan tinggi ke dalam berbagai mata kuliah. Walaupun dalam format kurikulum pendidikan tinggi belum menjadi suatu kurikulum dengan sejumlah mata kuliahnya yang berdiri sendiri.
\end{abstract}

\section{Kata Kunci : Pendidikan Multikultural, Kurikulum}

\section{MULTICULTURAL EDUCATION IN CURRICULUM DEVELOPMENT COLLEGE}

\begin{abstract}
Development and the implementation of education multikultur on higher education, can be packaged in charge like education kewargaanegaraan curriculum, principle education multicultural marriages, the education mutikultural and education kinds done and could be done through hidden curriculum or touch in the context of moral development noble, having intensity to coach and develop peace between religion. Then sends them upon whomever it is, the multicultural education achieve its appearance that can included on the list of college of heralds a college curriculum high into the range of the eye a college friend of. Even though in the format of an the curriculum of higher education has not yet become a the curriculum with a number of the eye those lectures which standing by itself.
\end{abstract}

\section{Keywords: multicultural education, curriculum}

Di era Ilmu Pengatahuan teknologi dan Informasi pendidikan menjadi topik yang selalu menarik perhatian bagi semua kalangan, utamanya para stakeholders pedidikan dan para 
praktisi pendidikan. Sebab, tema dan pendekatan yang dilakukan sangat variatif. Salah satunya yang menjadi isu nasional dan international dewasa ini adalah pendidikan dengan multikulturalisme, yang menjadi embrio konsep pendidikan multikultural. Menurut Choirul M. Menjelaskan bahwa, wacana pendidikan multikultural ini dimaksudkan untuk merespons fenomena konflik etnis, sosial, budaya yang kerap muncul ditengah-tengah masyarakat yang berwajah multikultural.

Wajah multikultural di negeri ini hingga kini ibarat api dalam sekam, yang suatu saat bisa muncul akibat suhu politik, agama, sosial budaya yang memanas, yang memungkinkan konflik tersebut muncul kembali. Tentu penyebab konflik banyak sekali tetapi kebanyakan disebabkan oleh perbedaan politik, suku, agama, ras, etnis dan budaya. Beberapa kasus yang pernah terjadi di tanah air yang melibatkan kelompok masyarakat, mahasiswa bahkan pelajar karena perbedaan pandangan sosial politik atau perbedaan suku, agama, dan ras tersebut (Choirul Mahfud, 2009). Terlepas dari kasus-kasus dalam negeri ada juga sejumlah masalah yang terjadi di jajira Arab sebagai akibat dari berpedaan pandanngan sosial politik yang melahirkan sektarian-sektarian yang berujung pada perbedaan suku, agama, ras.

Dengan demikian konsep pendidikan multikultural lahir dari sebuah refleksi dalam suatu kelompok. Isu-isu yang diangkat oleh penedidik multikultural mencakup: ras, suku, kelas, sosial, ekonomi, jender, ketidakmampuan, perbedaan usia, dan bahasa. Kemunculan isu-isu tersebut tidak lebih merupakan sebuah refleksi dari kondisi masyarakat yang mengalami ketimpangan dan ketidakadilan. Untuk itu hal ini menjadi kenisyaan untuk memikirkan alternati-alternatif pemecahanya, dalam hal ini adalah kalangan pendidikan. Pendidikan sudah sepatutnya berkontribusi dalam menyelesaikan berbagai konflik yang terjadi di masyarakat. Minimal pendidikan harus mampu memberikan penyadaran dan pencerdasan kepada masyarakat bahwa konflik bukan suatu hal yang baik untuk dibudayakan. Sepatutnya pula pendidikan mampu memberikan tawaran-tawaran yang mencerdaskan, antara lain dengan cara mendesain model pembelajaran, strategi hingga pengembangan kurikulum yang mampu menyadarkan masyarakat akan pentingya sikap saling toleran, tenggang rasa, menghormati perbedaan suku, agama, ras etnis dan budaya masyarakat Indonesia yang multikultural.Sudah selayaknya pendidikan berperan sebagai media transformasi sosial budaya dan multikulturalisme.

Menurut Fuad Fanani menjelaskan bahwa unsur utama dalam pendidikan multikultural adalah penempatan posisi peesrta didik dan mahasiswa sebagai subjek yang bersifat sejajar. Tidak ada superioritas satu komponen kultural seorang mahasiswa terhadap mahasiswa lainnya. Maka pendidikan multikultural ini dapat melatih dan membangun karakter siswa mampu bersikap demokratis, humanis dan pluralis dalam lingkungan mereka. Pendidikan multikultural memiliki posisi strategis dalam memberikan sumbangsih terhadap penciptaan perdamaian dan upaya penanggulangan 
konflik. Sebab nilai-nilai dasar dari pendidikan ini adalah penanaman dan pembumian nilai toleransi, empati, simpati dan solidaritas social (A. Fuad Fanani, 2004).

Masyarakat tidak bersifat statis. Seiring dengan kemajuan ilmu pengetahuan dan teknologi masyarakat selalu mengalami perubahan bergerak menuju perkembangan yang semakin kompleks. Perubahan tersebut tidak hanya terjadi pada sistem nilai, tetapi juga pada pola kehidupan, struktur sosial, kebutuhan, dan tuntutan masyarakat (Wina Sanjaya, 2006). Kurikulum, sebagai inti proses pendidikan di sekolah adalah aspek terpenting untuk menuangkan kepedulian sekolah pada kebudayaan masyarakat. Melalui kurikulum nilai-nilai budaya masyarakat diwariskan, dikaji, dan ditanamkan, serta dikembangkan bahkan direkonstruksi kembali selaras dengan perkembangan zaman.

Berdasarkan fenomena di atas, maka sudah sepatutnya wawasan multikulturalsisme disosialisasikan dalam dunia pendidikan tapi perlu diwujudkan sebagai kurikulum dalam perbagai jenjang pendidikan terutama di perguruan tinggi. Pemikiran tentang multikulturalisme sangat penting utamanya dalam memupuk rasa persatuan dan kesatuan bangsa sesuai dengan semangat kemerdekaan RI 1945 sebagai tonggak sejarah berdirinya Negara Kesatuan Republik Indonesia (NKRI). Tulisan ini mendeskripsikan bagaimana konsep pendidikan multikultural dalam mengembangkan kurikulum "Multikultural” di perguruan tinggi. Dengan tujuan untuk memberikan sebuah eksposisi terhadap konsep pendidikan multikultural di Indonesia, sehingga menjadi kontribusi dalam usaha mentransformasikan nilai-nilai kearifan lokal yang mencerminkan pemikiran dan jiwa nasionalisme.

\section{METODE PENELITIAN}

Penelitian Ini adalah kajian pustaka atau library research yang bertujuan untuk menngambarkan konsep pendidikan multicultural di Perguruan Tinggi

\section{HASIL DAN PEMBAHASAN}

\section{Konsep Pendidikan Multikultural}

Sebagai sebuah isu baru pengertian pendidikan multikultural sesungguhnya belum begitu jelas dan masih diperdebatkan oleh para pakar pendidikan. Namun bukan berarti definisi pendidikan multikultural tidak ada atau tidak jelas. Pendidikan multikultural masih diartikan sangat ragam, dan belum ada kesepakatan, apakah pendidikan multukiultural tersebut berkonotasi pendidikan tentang keragaman budaya, atau pendidikan untuk membentuk sikap agar menghargai keragaman budaya. Kondisi dan fenomena keragaman bangsa Indonesia menjadi faktor yang harus diperhatikan dan diperhitungkan serta dipertimbangkan untuk dijadikan program pendidikan secara mandiri. Kenyataan budaya yang multikultural dalam konteks ini sabagai landasan dalam membuat konsep dan mengembangkan visi. misi, tujuan dari berbagai komponen pendidikan (Nana Syaodih Sukmadinata, 2004). 
Pendidikan multikultural secara sederhana dapat didifinisikan sebagai pendidikan utuh tentang kebudayaan dalam merespon perubahan demografis dan kultural lingkungan masyarakat tertentu atau bahkan dunia secara keseluruhan (Azumardi Azra, 2004). Menurut Kamanto Sunarto dalam Naim, Ngainun dan Achmad Sauqi, menjelaskan bahwa Pendidikan multikultural biasa diartikan sebagai pendidikan keragaman budaya dalam masyarakat, dan terkadang juga diartikan sebagai pendidikan yang menawarkan ragam model untuk keragaman budaya dalam masyarkat, dan terkadang juga diartikan sebagai pendidikan untuk membina sikap siswa agar menghargai keragaman budaya masyarakat (Naim, Ngainun dan Achmad Sauqi, 2008). Sementara itu, Calarry Sada dalam Azumardi Azra dengan mengutip tulisan Sleeter dan Grant, menjelaskan bahwa pendidikan multikultural memiliki empat makna (model), yakni, (1) pengajaran tentang keragaman budaya sebuah pendekatan asimilasi kultural, (2) pengajaran tentang berbagai pendekatan dalam tata hubungan sosial, (3) pengajaran untuk memajukan pluralisme tanpa membedakan strata sosial dalam masyarakat, dan (4) pengajaran tentang refleksi keragaman untuk meningkatkan pluralisme dan kesamaan (Azumardi Azra, 2004)

Walupun ada beragam definisi pendidikan multikultural yang kemukakan di atas, kenyataan bangsa Indonesia terdiri dari banyak etnik, dengan keragaman budaya, agama, ras dan bahasa. Indonesia memiliki falsafah berbeda suku, etnik, bahasa, agama dan budaya, tapi memiliki satu tujuan, yakni terwujudnya bangsa Indonesia yang kuat, kokoh, memiliki identitas yang kuat, dihargai oleh bangsa lain, sehingga tercapai cita-cita ideal dari pendiri bangsa sebagai bangsa yang maju, adil, makmur dan sejahtera. Untuk itu, seluruh komponen bangsa tanpa membedakan etnik, ras, agama dan budaya, seluruhnya harus bersatu pada, membangun kekuatan di seluruh sektor, sehingga tercapai kemakmuran bersama, memiliki harga diri bangsa yang tinggi dan dihargai oleh bangsabangsa lain di dunia. Dalam konteks ini pendidikan multikultural melihat masyarakat secara lebih luas.

Berdasarkan pandangan dasar bahwa sikap "indifernece" dan "non-recognition" tidak hanya berakar dari ketimpangan struktur sosial tetapi paradigma pendidikan multikultural mencakup subjek-subjek mengenai ketidakadilan, kemiskinan, penindasan, keterbelakangan kelompok-kelompok minoritas dalam berbagai bidang sosial, budaya, ekonomi, pendidikan dan lain sebagainnya. Paradigma seperti ini akan mendorong tumbuhnya kajian-kajian tentang 'ethnic studies' untuk kemudian menemukan tempatnya dalam kurikulum pendidikan sejak dari tingkat dasar sampai perguruan tinggi. Dengan demikian, pendidikan multikulral dalam konteks ini akan diartikan sebagai sebuah proses pendidikan yang memberi peluang sama pada seluruh anak bangsa tanpa membedakan perlakuan karena perbedaan etnik, budaya dan agama, yang memberikan penghargaan terhadap keragaman, dan yang memberikan hak-hak sama bagi etnik minoritas, dalam upaya memperkuat persatuan dan kesatuan, identitas nasional dan citra bangsa di mata dunia international. 


\section{Pengembangan Kurikulum Multikultural Di Perguruan Tinggi}

Secara konseptual menurut Oliva (1997) dalam Hamid Hasan kurikulum adalah parangkat pendidikan yang merupakan jawaban terhadap kebutuhan dan tantangan masyarakat. Pengertian kurikulum ini sangat fundamental dan menggambarkan posisi sesungguhnya kurikulum dalam suatu proses pendidikan. Ketika kurikulum dianggap sebagai the heart of education (Klein, 1999) maka jantung pendidikan ini harus dapat diletakan pada posisi sesungguhnya. Proses pengembangan kurikulum harus mengkaji tantangan yang masyarakat dalam berbagai demensi kehidupan, mengkaji tantangan tersebut untuk menemukan kualitas yang perlu dimiliki manusia Indonesia sebagai manifestasi dari sebuah proses pengembangan kurikulum yang ideal.

Menurut Hamid Hasan keseluruhan proses pembangan kurikulum dengan pengembangan empat dimensi kurikulum. Keempat dimensi tersebut ialah:

a. Kurikulum dalam dimensi ide, berkenaan dengan landasan filosofis dan teoritis kurikulum. Artinya aspek filosofis ini terlihat apakah kurikulum dikembangkan untuk menjawab kebutuhan masyarakat dalam pengembangan disiplin ilmu, teknologi, agama, permasalahan sosial buadaya, ekonomi, kebangsaan dan lain-lain.

b. Kurikulum dalam dimensi dokemen, maka kurikulum berisikan komponen; tujuan conten, proses dan assesmen.

c. Kurikulum dalam dimensi proses adalah implementasi dari apa yang direncanakan dalam dimensi dokumen.

d. Kurikulum dalam dimensi hasil adalah apa yang dimiliki oleh peserta didik/mahasiswa

Dalam kaitanya dengan penjelasan tersebut, kondisi dan fenomena keragaman bangsa Indonesia sebagai negara majemuk baik dalam segi agama, suku bangsa, golongan maupun budaya lokal perlu menyusun konsep pendidikan multikultural sehingga menjadi pegangan untuk memperkuat identitas nasional, mata kuliah kewarganegaraan yang telah diajarkan di perguruan tinggi, yang mencerminkan pendidikan multikultural, seperti kearifan lokal antar daerah kedalamnya, agar generasi muda bangga sebagai bangsa Indonesia

Dengan demikian Pendidikan multikultural sebagai sebuah rekonstuksi kurikulum yang mencerminkan empat dimensi pengembangan kurikulum. Oleh karena itu pendidikan mulitikutural bukan sebagai kurikulum tersembunyi (hidden curriculum). Pendidikan multikultur adalah pendidikan nilai yang harus ditanamkan pada siswa sebagai calon warga negara, agar memiliki persepsi dan sikap multikulturalistik, bisa hidup berdampingan dalam keragaman watak kultur, agama dan bahasa, menghormati hak setiap warga negara tanpa membedakan etnik mayoritas atau minoritas, dan dapat bersama-sama membangun kekuatan bangsa sehingga diperhitungkan dalam percaturan global dan nation dignity yang kuat. 
Menurut Hamid Hasan, bahwa masyarakat dan bangsa Indonesia memiliki keragaman sosial, budaya, aspirasi politik dan kemampuan ekonomi. Keragaman tersebut berpengaruh langsung terhadap kemampuan pendidik dalam melaksanakan kurikulum, kemampuan lembaga pendidikan dalam menyediakan pengalaman belajar dan kemampuan peserta didik dalam berproses, belajar dan mengolah informasi menjadi sesuatu yang dapat diterjemahkan sebagai hasil belajar. Keragaman itu menjadi suatu variabel bebas yang memiliki kontribusi sangat signifikan terhadap keberhasilan kurikulum, baik sebagaiproses maupun sebagai hasil.

Pengembangan kurikulum dengan menggunakan pendekatan pengembangan multikultural harus didasarkan pada empat prinsip; (1) keragaman budaya menjadi dasar dalam menentukan filsafat. (2) keragaman budaya dijadikan dasar dalam mengembangkan berbagai komponen kurikulum, seperti tujuan, konten, proses, dan evaluasi. (3) budaya di lingkungan unit pendidikan adalah sumber belajar dan objek studi yang harus dijadikan bagian dari kegiatan belajar. (4) kurikulum berperan sebagai media dalam mengembangkan kebudayaan daerah dan nasional. Sejalan dengan penjelasan tersebut, untuk itu rancangan kurikulum ini diarahkan untuk melestarikan nilai-nilai budaya masyarakat. Dalam perspektif ini, kurikulum merupakan perencanaan untuk memberikan pengetahuan dan keterampilan kepada anak didik/mahasiswa sebagai persiapan menjadi orang dewasa yang dibutuhkan dalam kehidupan bermasyarakat. Yang dijadikan dasar oleh para perancang kurikulum adalah aspek-aspek penting kehidupan bermasyarakat.

Pengembangan dan Implementasi pendidikan multikultur pada pendidikan tinggi, dapat dikemas kedalam muatan kurikulum seperti pendidikan kewargaanegaraan, prinsipprinsip pendidikan multikultural, landasan pendidikan mutikultural dan Pendidikan Keberagamaan dilakukan serta dapat dilakukan melalui hidden kurikulum atau sentuhan dalam konteks pembinaan akhlak mulia, memiliki intensitas untuk membina dan mengembangkan kerukunan hidup antar umat beragama. Kemudian, juga harus dilakukan dalam pendekatan deduktif dengan kajian yang relevan, kemudian dikembangkan menjadi norma-norma keagamaan, norma hukum, etik, maupun norma sosial kemasyarakatan. Pendidikan multikultur harus dilakukan secara komprehensif, dimulai dari desain perencanaan dan kurikulum melalui proses analisia kebutuhan, pengayaan dan atau penguatan terhadap berbagai kompetensi yang telah ada, mendesain proses pembelajaran yang bisa mengembangkan sikap mahasiswa untuk bisa menghormati hakhak orang lain, tanpa membedakan latar belakang ras, agama, bahasa dan budaya. Dan terakhir pencapaian hasil pendidikan dan pencapaian pendidikan multikultur harus dapat terukur melalui evaluasi yang relevan, apakah melalui instrumen tes, non-tes berupa pengamatan, jurnal, penilaian sesama teman, penilaian diri portofolio secara berkesinambungan. 
Beberapa kompetensi dasar yang dikembangkan melalui pendidikan multikultural adalah:

a. Menjadi warga negara yang menerima dan menghargai perbedaan-perbedaan etnik, agama, bahasa dan budaya dalam struktur masyarakatnya

b. Menjadi waraga negara yang bisa melakukan kerjasama multi etnik, multi kultur, dan multi religi dalam konteks pengembangan ekonomi dan kekuatan bangsa

c. Menjadi warga negara yang mampu menghormati hak-hak individu warga negara tanpa membedakan latar belakang etnik, agama, bahasa dan budaya dalam semua sektor sosial, pendidikan, ekonomi, politik dan lainnya, bahkan untuk memelihara bahasa dan mengembangkan budaya mereka.

d. Menjadi warga negara yang memberi peluang pada semua warga negara untuk terwakili gagasan dan aspirasinya dalam lembaga-lembaga pemerintahan, baik legislatif maupun eksekutif.

e. Menjadi warga negara yang mampu mengembangkan sikap adil dan mengembangkan rasa keadilan terhadap semua warga negara tanpa membedakan latar belakang etnik, agama, bahasa dan budaya mereka.

Kelima kompetensi dasar tersebut sebagai jantungnya pendidikan multikultur dengan harapan agar menghasilkan warga negara yang memiliki sikap dan kebiasaan multikultur dengan sikap dan perilaku yang toleran antar semua anak bangsa, solider dan bisa saling bekerjasama untuk kepentingan bangsa, bersikap egaliter, memiliki sikap empati sesama warga, dan bersikap adil dengan tidak membedakan latar belakang agama, ras, bahasa dan warna kulit.

Sejalan dengan konsepsi ini, Jhon Dewey merekomendasikan tiga hal yang harus dipertimbangkan dalam mengembangkan sebuah kurikulum. "Pertama, hakikat dan kebutuhan peserta didik. Kedua, hakikat dan kebutuhan masyarakat. Dan ketiga, masalah pokok yang digumuli peserta didik untuk mengembangkan diri sebagai pribadi yang matang dan mampu menjalin hubungan dengan pribadi lain dalam masyarakat". Dengan demikian pendidikan multikultur harus direkonstruksi dalam sebuah desain pengembangan kurikulum yang integratif, sekuensial dan didukung dengan lingkungan serta struktur dan budaya yang bisa memberikan impec positif terhadap pembentukan sikap dan perilaku multikultur. Pendidikan multikultur, secara substansial harus bisa menjadi sebuah kurikulum sendiri pada perguruan tinggi yang harus terjabar kedalam berbagai mata kuliahnya sendiri-sendiri seperti pengantar pendidikan mulitikultural, landasan-landasan pendidikan multikultural dan pendidikan keberagamaan.

\section{KESIMPULAN}

Pendidikan multikultural sebagai wadah pendidikan untuk menjadi solusi bagi konflik dan disharmonisasi yang terjadi di masyarakat. Dengan kata lain pendidikan multikultural menjadi sarana alternatif pemecahan konflik sosial budaya. Dan pendidikan 
multikultural sebagai sarana alternatif pemecahan konflik danbudaya. Pengertian pendidikan multikultural lahir dari sebuah refleksi dalam suatu kelompok. Isu-isu yang diangkat oleh penedidik multikultural mencakup: ras, suku, kelas, sosial, ekonomi, jender, ketidakmampuan, perbedaan usia, dan bahasa. Kemunculan isu-isu tersebut tidak lebih merupakan sebuah refleksi dari kondisi masyarakat yang mengalami ketimpangan dan ketidakadilan. ini diartikan sebagai sebuah proses pendidikan yang memberi peluang sama pada seluruh anak bangsa tanpa membedakan perlakuan karena perbedaan etnik, budaya dan agama, yang memberikan penghargaan terhadap keragaman, dan yang memberikan hak-hak sama bagi etnik minoritas, dalam upaya memperkuat persatuan dan kesatuan, identitas nasional dan citra bangsa di mata dunia.

\section{SARAN}

Perlu adanya kajian yang lebih dalam tentang kurikulum berbasis ultikultural pada perguruan tinggi yang bercirikan kebihnekaan sehingga akan diperoleh pola perencanaan kurikulum yang tepat dan sesuai dengan karakter perguruan tinggi

\section{DAFTAR PUSTAKA}

Azumardi Azra. 2004. Pendidikan Multikultural (Membangun Kembali Indonesia Bhineka Tunggal lka). http: www. Republika.co.id/kolom detailasp 2004.

Choirul Mahfud. 2009. Pendidikan Multikultural. Pustaka Pelajar. Yogyakarta

A. Malik Fajar. 1998. Visi Pembaruan Pendidikan Islam. LP3NI. Jakarta.

Fanani, Fuad A. 2004. Islam Mazhab Kritis: Menggagas Keberagamaan Liberati. Kompas Gramedia. Jakarta.

Hasan, Hamid S. 2000. Multikulturalisme Untuk Penyempurnaan Kurikulum Nasional. Jurnal Pendidikan dan Kebudayaan. Vol.026,No. 6.

2007. Pengembangan Kurikulum Tingakat Satuan Pendidikan. Jurnal Inovasi Kurikulum Himpunan Pengembang Kurikulum Indonesia. Vol. 1.No. 1.

Naim, Ngainun dan Achmad Sauqi. 2008. Pendidikan Multikultural Konsep dan Aplikasi. A-Ruzz Media. Jogjakarta.

Wina Sanjaya. 2006. Pembelajaran Dalam Implementasi Kurikulum Berbasis Kompetensi. Kencana, Prenada Media Group. Jakarta. 2010. Kurikulum dan Pembelajaran (Kurikulum Tingkat Satuan Pendidika), Kencana, Prenada Media Group. Jakarta. 